\title{
Uncovering Discursive Framings of the Bangladesh Shipbreaking Industry
}

\author{
S. M. Mizanur Rahman ${ }^{1, *}$, Chelsea Schelly ${ }^{2}$, Audrey L. Mayer ${ }^{2,3}$ (1) and Emma S. Norman ${ }^{4}$ \\ 1 CREIDD Research Center on Environmental Studies \& Sustainability, Department of Humanities, \\ Environment \& Information Technology, Institut Charles Delaunay, CNRS-UMR 6281, \\ University of Technology of Troyes, 10300 Troyes, France \\ 2 Department of Social Sciences, Michigan Technological University, 1400 Townsend Dr., Houghton, MI 49931, \\ USA; cschelly@mtu.edu (C.S.); almayer@mtu.edu (A.L.M.) \\ 3 School of Forest Resources and Environmental Science, Michigan Technological University, \\ 1400 Townsend Dr., Houghton, MI 49931, USA \\ 4 Department of Native Environmental Science, Northwest Indian College, Bellingham, WA 98229, USA; \\ enorman@nwic.edu \\ * Correspondence: ssmmizan@mtu.edu or sm.mizanur_rahman@utt.fr
}

Received: 13 November 2017; Accepted: 17 January 2018; Published: 19 January 2018

\begin{abstract}
Shipbreaking in the Chittagong region of Bangladesh supplies metal to meet the needs of the nation's construction sector. The shipbreaking industry has received international attention for environmental contamination and workers' insecurity. However, these issues have been framed without considering the actors that produce them and their associated motives. This paper illuminates the conflicting discourses regarding the industry between two divergent groups of actors. On the one hand, national and international NGOs collaborate to enforce a discourse focused on negative localized impacts. On the other hand, yard owners, yard workers, and local community members forge a counter discourse, focused on positive localized impacts and raising doubts about the origin of the environmental pollutants and occupational standards setting. National and international actors have so far missed the conflicting perspective of workers, yard owners, locals and NGOs. We contend that these divergent discourses involve scalar politics, with one discursive frame focused on localized impacts in order to leverage global resources, while the other situates local communities in the global world system; this confounding of scale leads to ineffective policy formulation. This shipbreaking case study provides a valuable lesson on the importance of listening to and including stakeholders at multiple scales when seeking policies to address localized impacts of a globalized industry.
\end{abstract}

Keywords: discourse; framing; politics of scale; shipbreaking; shiprecycling; environmental contamination; working condition

\section{Introduction}

The storyline seems relatively straightforward: billion-dollar shipbreaking companies from core geographical centers of wealth find ports of economically marginalized countries, with little to no environmental or worker safety regulations, to recycle vessels that provide a critical metal supply for the construction sector in those peripheral nations (Cairns 2014; Sujauddin et al. 2014; Frey 2015; Rahman and Mayer 2015). Bangladesh is a prime example of the issues representing the operations of the global shipbreaking industry in peripheral countries. Scientific research has illustrated the consequent environmental contamination (e.g., heavy metals, oil spills, etc.) and its impacts on the local ecology in Chittagong, Bangladesh (Hossain and Islam 2006; Siddiquee et al. 2012; Abdullah et al. 2013; Rahman et al. 2016; Sharifuzzaman et al. 2016). Industrial enterprises established along the coast in 
Bangladesh use marine areas as a sink for their effluents, often surpassing threshold limits of the local ecosystems to absorb them (Siddiquee et al. 2012; Sharifuzzaman et al. 2016).

Shipbreaking also raises concerns regarding human rights for workers who confront serious occupational accidents and injuries, an issue particularly salient for NGOs across local (Youth Power in Social Action, abbreviated YPSA), national (Bangladesh Environmental Lawyers Association, abbreviated BELA) and international (Greenpeace, NGO shipbreaking platform, and International Federation for Human Rights, abbreviated FIDH) scales, as well as the United Nations International Labor Organization (ILO). In the Bangladeshi shipbreaking industry, on average, 10-15 workers are killed and 150 are injured every year (Sujauddin et al. 2014; Bailey 2000; Andersen 2001). The most frequent causes of death include gas explosions while using gas torches for cutting, suffocation from inhaling toxic gases, and sudden falls from steel beams and plates. Common injuries include deep lacerations, broken bones, loss of limbs, and fainting/unconsciousness (Hossain et al. 2008). In addition to these direct occupational harms, indirect harms result from exposure to hazardous chemicals and inhalation of toxic gases, causing health impacts that often appear years after leaving shipbreaking work.

This is a representation of Bangladesh shipbreaking that only objectivizes the phenomenon with no references to the human interventions that construct this environmental and worker representation. "Who is playing what games" remains relatively unexplored regarding shipbreaking (Cairns 2007; Crang 2010; Demaria 2010; Devault et al. 2017). Demaria (2010) employs discourse analysis to discover multiple interpretations of the acceptance of Le clemenceu in India from NGOs, national government officials and international authorities, and concludes that the phenomenon is an "ecological distribution conflict." What is lacking in his study is the contextualization of institutional standards of the shipbreaking nations that differ from developed countries. This oversight is addressed in Cairns (2007), who illustrates how representation often assumes a western standard and thus requires careful scrutiny of the motive/s of representation (Crang 2010). Crang (2010) articulates how photography of shipbreaking activities constructs a sympathetic reality, contrasting bodies of workers with giant ships and ship parts together, arguing that whether workers were victimized or not becomes less concerning than the photographer's intention to frame shipbreaking as a horrific reality (Gregson 2011). Devault et al. (2017) argue that the representation of shipbreaking issues in peripheral countries reflects as though the breaking activities are occurring in yards of developed countries.

These critiques of shipbreaking lack an attempt to properly humanize the struggle of situating issues-who plays what role-and how and why the actors play such roles in articulating representations. This study draws on discursive theory and politics of scale under the broader area of third world political ecology and contributes to the shipbreaking literature to enlighten the ways the reality is constructed. This study sheds light on two categories of actors: NGOs and industry workers. The NGOs include local NGOs, Youth Power in Social Action (YPSA 2017) and Bangladesh Environmental Lawyer Association (BELA), while the industry workers include yard owners, yard officials, and yard workers, invoking issues in different scales that serve their interests. We argue that these divergent actor groups engage in scalar politics, with one discursive frame focused on localized impacts in order to leverage global resources while the other contextualizes them in the global world system while utilizing party politics as a means of power to pursue their current practices. We also argue that these divergent discourses obscure the identification of viable solutions to existing environmental and social problems and contribute to ineffective policy implementation.

\section{Discourse, Framing and Politics of Scale}

This research examines discourse to understand the stakeholders' experiences and perceptions using an interpretive paradigm that entails the understanding of the social and cultural reality founded in actors' observations and attaches meaning to it (Crotty 1998). The term discourse refers to "a collective way of apprehending and comprehending the world" (Rafey and Sovacool 2011, p. 1142). Discourses can be assembled into discursive frames, with framing referring to a process through which 
an intersubjective meaning is constructed to facilitate organizational goals (Snow and Benford 1988; Benford 1993; Bickerstaff and Agyeman 2000; Fiss and Hirsch 2005; Doulton and Brown 2009). Discursive frames provide coherence to the standpoints, meaning, ideologies and interests advanced by a set of institutions (Peet and Watts 1996).

The positionality of the actors involved impacts the production and maintenance of discursive frameworks (Wiktorowicz 2004). How do politics comes into play? Douglas and Wildavsky (Douglas and Wildavsky 1983, p. 65) write, "estimation of risk is a scientific question but the acceptability of risk is a political question." The actors representing a particular discourse emerge in "establishing acceptability rather than facts, from correct answer to agreed conclusions" (Douglas and Wildavsky 1983) (p. 66). Foucault (1980) argues that power is exercised through a process of socialization that creates a "superior opportunity structure" (Hannigan 2006) (p. 54). In other words, a contested discursive formation can develop among different social groups, leading to the formation of a discursive strategy (productive network) and dispositive (including non-discursive practices) (Foucault 1980; Bickerstaff and Agyeman 2009). A discursive framing matures through the gradual enrollment of human allies as well as non-human intermediaries and through competing representations and interactions (media, internet, websites, reports, leaflets), or the scalar politics of social actors (Hannigan 2006; Bickerstaff and Agyeman 2009; Kurtz 2003; Andsager 2000; Ferree 2002, p. 54). Thus, playing around subjective (for example, risk takers or risk averse) vs. objective (risk assessment methods and results) dimensions symbolizes contestation. For example, a risk takers' frame intends to calculate wealth gain vs. health loss while a risk-averse frame insists on the sanctity and pricelessness of life and demonizes attempts that compare "life lost" with money. This dichotomy potentially generates scale politics between risk takers (workers, yard owners and perhaps government officials) and the risk averse (NGOs and Scientists) and insinuates a complex landscape of interests. Breaking free of such complexities, as Foucault (1980) suggests, requires examining the events in differing levels. For example, workers' preferences deserve examination because "they are experts of their own feelings and choice alternatives" (Douglas and Wildavsky 1983; Foucault 1980).

Discourses exert social pressure; they manifest power over others through instruments, techniques and procedures, becoming "truths" (Foucault 1980) or "accepted wisdom" (Leach and Mearns 1996). Escobar (1998) maintains that discourse organizes the production of forms of knowledge by linking actors and institutions that share knowledge streams into networks. Through these networks, discourse re-inscribes and empowers itself to create knowledge-power constellations (Said 1979; Mitchell 1991; Adger et al. 2001; Escobar 2011; Robbins 2011). Leach and Mearns (Leach and Mearns 1996, p. 441) show that views of environmental change are "popularized in the news and current affairs media in developed and developing countries ... to build support [for] charitable organizations [through] images of starving children and attribution of blame."

Discursive framings often deploy politics of scale to construct a particular mental map of a phenomenon (Kaiser and Nikiforova 2008; Harris and Alatout 2010; Norman et al. 2012). Over the last two decades, the link between environmental governance and scalar politics has received a lot of attention (Harris and Alatout 2010; Swyngedouw 2000; Swyngedouw and Heynen 2003; Brown and Purcell 2005). Functionally, actors merge actions across scales to form a space of engagement in which issues regarding the space of dependence are defined and worked out (Cox 1998; Marston 2000). The term "space of dependence" is defined here as the specific conditions upon which actors depend for the realization of their interests, and "the space of engagement" is a network of association residing at different scales to secure the conditions in the space of dependence (Cox 1998; Lebel et al. 2005). Space is a composite of multiple subjectivities as well as a multiplicity of representations that manipulate narratives through inclusion or exclusion, presence or absence and making something visible or pushing disappearance (Cox 1998; Hillier 2009). Litfin (1994) (pp. 3, 14) writes, "As determinants of what can and cannot be thought, discourses delimit the range of policy options, thereby functioning as precursors to policy outcomes. ( . . . ) The supreme power is the power to delineate the boundaries of thought-an attribute not so much of specific agents as it is of discursive practices." The contestation 
among actors is, thus, in what is excluded or included, absent or present and visible or disappeared and builds through strategic association of actors, organizations and institutions.

\section{Study Area}

The Bangladesh shipbreaking yards provide a significant source of metal and steel to meet local demand due to the absence of virgin iron ore in the country. More than $70 \%$ of domestic steel demand is met by the shipbreaking yards along the coast (Saraf et al. 2010). The yards also provide employment for more than 50,000 people directly and more than 100,000 people indirectly (Hossain and Islam 2006; Saraf et al. 2010). This industry recycles and reuses metal scraps that contribute to the reduction of global environmental impacts, by reducing the need for the mining of virgin iron ores (Rahman et al. 2016). The shipbreaking yards are situated in Sitakunda Thana, Chittagong. There are about 100 yards operating along the coastal areas in Sitakunda, mainly in Kumira, Bhatiary and Fouzdarhat. The yards occupy only about $4000 \mathrm{~m}^{2}$ of land, representing intense economic activity per square meter of land (Rahman and Mayer 2015). Figure 1 (top left and right) shows a typical yard where ships are broken into pieces and the outputs are loaded and transported to the market for sale. The ship that is half dismantled and the one that has just a small remaining internal structure at the far right side of the top right photo belong to different yards; this illustrates the small size of each yard. The ships are first dismantled into bigger sections, and then those bigger sections are dragged by the winch during high tide to the end of the muddy areas beyond the water line. Cutter men use blowtorches to cut these large sections into smaller sections, which are then carried by the magnetic grabs (in the foreground) to the trucks (top right photo in Figure 1). Any small, lightweight pieces are carried by the workers from the ships into the dry areas and organized into categories to be sold. A massive scale (top left) weighs both unloaded and loaded trucks to measure the amount of metal sold. This equipment may reduce the amount and weight of metal that workers must carry from the ships to the yards. A local trader is selling glasswool in a local market (top middle). The small section is waiting to be sold in Dhaka city and the workers are seen shouldering the small section in the Dhaka city (lower middle). The lower right picture shows the working conditions in the Dhaka city scrap-processing zone.

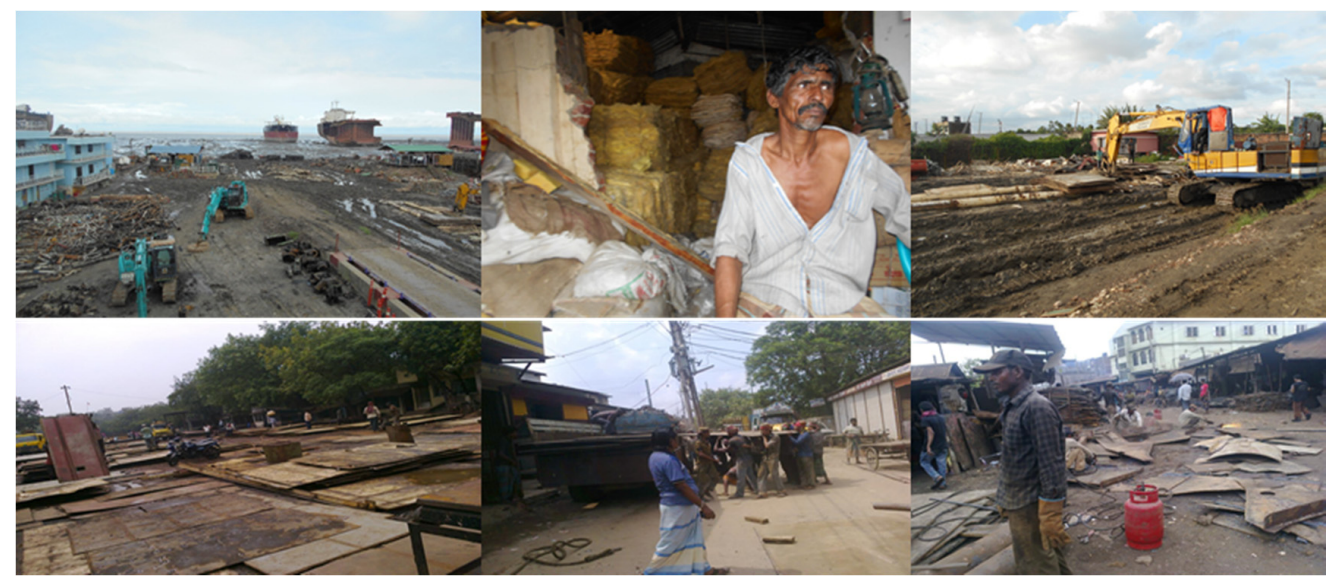

Figure 1. Shipbreaking yard with grab (top left), glasswool shop in Bhatiraty (top middle), magnetic grab carrying small sections for loading (top right). Shipbreaking scrap business in Dhaka city (bottom left), workers carrying plate in shoulder in Dhaka city (bottom middle), Cutters working in Dhaka city (bottom right). Photo Credit: First author, 14 June 2014.

\section{Methodology}

In this work, we have adopted methodologically contextual categories to address the following questions: What are the dimensions of attitudes or perceptions of the stakeholders? What is the nature 
of people's experiences? (Ritchie and Spencer 2002). To capture perspectives from multiple actors involved with the shipbreaking industry, the lead author-who is originally from Bangladesh and whose native language is Bengali-spent two field seasons studying the shipbreaking industry at the yards and in the nation's capital, Dhaka. From May through August 2014, and December 2014 through March 2015, fieldwork was conducted by being physically present in multiple shipbreaking yards, observing the activities of the shipbreaking industry, taking ethnographic notes, and conducting formal and informal interviews in Bengali-translated later into English-with a diverse range of actors.

A grounded theory approach was followed to formulate research design, data collection and analysis (Strauss and Corbin 1997; Charmaz and Belgrave 2007). Data collection involved four steps: conducting interviews and taking notes of field observations; listening to the recorded interview and reading the interview notes to identify emergent codes and information on a daily basis; incorporating emergent respondents from interviews; and, finally, writing memos and interpretation. The detailed process is dynamic and continuously reorganizes the set of respondents based on the emergent properties of the collected data regularly. The strength of this approach, as is seen below, is the collection of novel information and understanding perceptions while employing a series of checks and refinements in an iterative process. A grounded theory approach, thus, allows researchers to consciously interpret and interact with the data in order to unearth the grounded reality (Strauss and Corbin 1997).

A diverse range of actors were interviewed, including yard owners and managers, yard workers (e.g., security guards, cutter men, loaders, foremen), metal recycling businessmen, NGO officials including from two environmental NGOs, researchers, academics, government officials including an official from the Department of Environment (DoE) (a government organization which used to supervise the shipbreaking yards) and several top officials of the Ministry of Industry (which is now responsible for overseeing the shipbreaking industry), and locals (e.g., mosque leaders, fishermen). This research project rests upon a total of 39 formal interviews (see Table 1) and many additional informal conversations. Employing both open-ended and closed questions, interview questions were tailored to the type of interviewee such that the questions would be relevant. The venue of the interviews ranged from working in the yard, in offices, and in homes. To avoid potential biases, workers were interviewed at the yards, outside of yards and at home. NGO documents, yearly reports, website content and leaflets were also analyzed.

Table 1. Actors and perspectives revealed through open-ended interviews in Bangladesh.

\begin{tabular}{ccl}
\hline Actors & No. of Interviews & \multicolumn{1}{c}{ Summary of Interviews } \\
\hline NGOs (YPSA and BELA) & 4 & $\begin{array}{l}\text { Yards did not improve and continue to pose a danger to } \\
\text { workers and the environment }\end{array}$ \\
\hline Yard owners/officials & 13 & $\begin{array}{l}\text { Yards have improved and the accidents are insignificant } \\
\text { compared to other industries. }\end{array}$ \\
\hline Workers & 5 & $\begin{array}{l}\text { Workers are both happy to work and realize the work is risky. } \\
\text { They want this industry and do not want it to stop. }\end{array}$ \\
\hline GOs (DOE, Ministry of Industry) & 4 & $\begin{array}{l}\text { The industry is much improved but needs international } \\
\text { investment to enhance capacity building. }\end{array}$ \\
\hline Professors & $\begin{array}{l}\text { There is a need to assess the sources of contamination; need } \\
\text { proper data to explore the issues. }\end{array}$ \\
\hline Local People (living near yards) & 10 & $\begin{array}{l}\text { Local people do not blame this industry for either } \\
\text { environmental contamination or risks to workers; as they } \\
\text { blame the other chemical industries in the area and; instead } \\
\text { they view this industry as a job opportunity. }\end{array}$ \\
\hline
\end{tabular}

Gaining access to the yards was difficult; first, the researcher tried to enter the yard but was stopped at the gate by security personnel. However, traders are entering into the gate but are not stopped by security, indicating that security officials either knew them or allowed them by looking 
at their locally appropriate outfit that pertains to general traders or customers. The researcher then tried to enter the yard with the traders but failed to pass security, then talked to one of the traders and asked for help to get into the yard but failed, then ended up being assisted by a second, elderly trader. After entering into the yard, observing the activities was possible but talking informally to workers was uncomfortable with both workers and supervisors in the yards, which lasted only a few hours. Yet the researcher stayed around to meet people, including traders and workers when they were coming out to the small teashop near the yard. On another day, the lead researcher was sitting at the pond on the other side of the yard across the road and talking to traders when an educated-looking man approached and asked several questions. After being introduced as a PhD researcher, the man introduced himself as a yard manager and asked the researcher to visit the yard, then staying there in the yard for two days and one night, having permission to take pictures and access to other surrounding yards through this yard (other yards are separated from the entry gate through the middle and open at the intertidal zone until the tidal zone). The second cluster of yards was entered from the west side through the entry gate (Figure 2). By this time, the researcher became familiar with the entry procedures to the yard and approached as a trader would. In one yard, he became acquainted with a yard officer, who helped him visit and showed him waste rooms and other equipment.

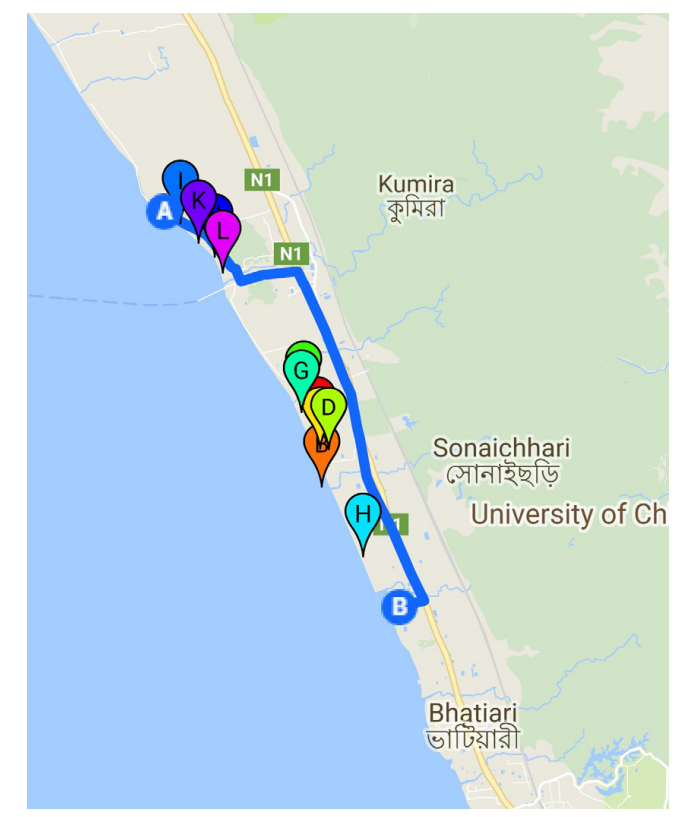

Figure 2. Yards visited during the field trips in Chittagong, Bangladesh, shown in Google map 2017. The yards A, B, C, D, E, F, G, H constitute first cluster while I, J, K, L constitute second cluster. The blue boundary signifies the total yard boundary in Bangladesh.

Ultimately, four yards were observed from the inside while nine others were viewed from the outside (Figure 2). All data collection methods were approved by the Human Subjects Institutional Review Board at Michigan Technological University. The former cluster of the yards in the east was accessed with the permission of the yard officials, as described above. The officials of one of the first yards informed the researcher that their yards are of the better sides. The other cluster in the west are smaller comparatively and less organized (Figure 2). The interview sample may not necessarily be representative, given the constraints and barriers to entry and the potential biases in entry permission into the yards (e.g., yards with better environmental and working conditions may have been more likely to allow entry). The interviews with stakeholders (local communities, fishers, rickshaw pullers, villagers, workers and traders) were representative with a good level of confidence to capture sufficient diverse information. 
The position of the researcher is that the content of discourses (text, wording, degree of emphasis, inclusion/exclusion, contexts, interests and networking) has a deeper analytical value in the construction of reality. The lack of any representative opinion from the international organizations and the shipping companies may be a limitation of this work. However, the addition of their interview may also not radically alter the discourses captured so far. The opinion of the local NGOs often represents the stance of the international environmental organizations and UN agencies, particularly the ILO. In addition, the shipping companies have little relevance to how the yards are operated in Bangladesh. However, interviews with diverse local people, some of whom were involved in yard activities while others were not, also triangulated the mutual biases of their concerns and perspectives, which is presented and analyzed in the following sections.

\section{Results}

The interviews reveal a diverse range of perspectives around the environmental and worker health impacts of the shipbreaking industry as well as its local benefits (Table 1). The interview data reveals divergent discourses that represent strategic scalar politics, with one discursive frame focused on localized impacts in order to leverage global resources, while the other situates local communities in the global world system. Interviewee responses could be broadly divided into two categories. One group, comprised of local and national NGOs such as YPSA and BELA, denied any improvement had occurred and believed that shipbreaking was extremely hazardous to both workers and the environment. A second group, including yard officials and yard workers as well as representatives from government, articulated that shipbreaking practices were improving, with some issues remaining to be addressed.

\subsection{Environmental Pollution: Inclusion and Exclusion Politics}

Research conducted in collaboration with NGOs on shipbreaking often identifies the shipbreaking yards as a major source of contaminants. For example, Siddiquee et al. (2012, p. 79) stated: "any discharge like spillage of oil, lubricant, grease, POPs [Persistent Organic Pollutants], etc. are spilled or thrown into the coast during the shipbreaking operation." This statement that exclusively identifies shipbreaking activities as the source of contaminant discharges to the water is contradicted by the statement in a later paragraph that states: "Heavy metals [are] introduced into the environment by dumping domestic and municipal wastes, industrial effluents, urban runoff, agricultural runoff, atmospheric depositions and incorporated into the marine sediments" (Siddiquee et al. 2012, p. 79). While the elements in the sediments are said to be sourced from a diversity of establishments, the title of the study, "Heavy Metal Pollution in Sediments at Shipbreaking Area", suggests that the shipbreaking industry is the primary source of the contamination.

NGO actors frame shipbreaking in terms of a major environmental contamination along the coast, maintaining that shipbreaking is the source. When asked how much of the pollutants the other chemical industries may discharge as compared to shipbreaking, one NGO official said, "The other chemical industries are discharging much less, at levels that may not have an impact." At the same time, an NGO representative acknowledged that the area in Sitakunda where shipbreaking occurs "is a zone of industrial [wastes] where all other chemical industries are operating with or without Effluent Treatment Plants (ETP), discharging waste effluent to the coastal water". Stressing the lower contaminant potentials of the neighboring industries, NGOs tend to "single out" the shipbreaking industry.

In a counter frame, one yard manager estimated one kilogram $(\mathrm{kg})$ waste per ton of recovered metal. He maintained, "We sell almost all of our waste, even the black oil, paint; just look at here [pointing to the waste room that stocks spent oil and paint, glass wools, asbestos etc.]." The yard manager contextualized the market demand for the scraps and invoked the cultural context in which the industry is located. Similarly, A DoE official remarked, "Look at the main rivers of our country. For example, consider Burigonga [a river that surrounds the capital city, Dhaka]. Why is the river water highly polluted? No shipbreaking activities are there except the chemical 
industries, garments industries, and tannery industries. Of course, those industries have high effluent discharges." The findings of Kibria et al. (2016) conform to the counter frame of yard officials and DoE officials, in that they show that sites that contain only shipbreaking industries observe less pollutant concentration than sites that contain other industries including shipbreaking. The high-impact sites are observed in Dhaka, with four of the seven heavy metals having higher concentration, whereas shipbreaking sites only observe one heavy metal, Cadmium (Cd), beyond threshold. Rahman et al. (2016) conducted a life cycle assessment on shipbreaking in Bangladesh and found that endpoint impact due to waste discharge in the coastal environment constitutes only $0.3 \%$ of the total impact, with the most impact from the rerolling stage that occurs outside the yard, across the country. While this study is only an exception to other pollution assessment studies in Bangladesh, this points to the general contamination of water bodies in Bangladesh. A local shopkeeper mentioned, "The textile factory [Sunman textiles] often discharges their wastes either at night or on a weekend during high tide, as the canal is filled up with water during high tide and pollutants become less noticeable when mixed with tidal saline water. This company received about a 9000 dollar fine by the Department of Environment." When asked about the fine, one DoE officer said that, "Yes, such cases happen, even I have fined many other industries around the area. The total fine this department issued may be around 10-15 crores taka [about 1 million USD]."

One local fisherman explained, "The reason for the gradual reduction of our catches could be traced to the factories situated in the higher hilly areas which discharge chemicals, dyes, and other poisonous pollutants into the waterways that even kill snakes in the streams." The recognition among local stakeholders is that this area is comprised of multiple industrial sectors, one or more of which may be responsible for the pollution observed along the coast.

Scientists examine pollutant potentials of shipbreaking and contribute to the claim made through measuring the concentration of pollutants in the coastal water and sediments near shipbreaking yards. YPSA and its international counterpart (NGO Shipbreaking platform) publish those scientific publications on their website, consolidating the process of pollution claim making (YPSA 2017). Yard officials counterframe the pollution claim by acknowledging the multiple sources of pollution in the area, based on the diverse activities taking place as a result of global relations of production. Yard officials also counter the pollution frame by saying that the waste still has usability in Bangladeshi communities, thereby potentially emerging as commodity (Rahman and Mayer 2015; Crang 2010; Gregson and Crang 2010; Gregson et al. 2010, 2012). NGOs focus on "singling out" the issue by excluding the "reuse culture of the waste" narratives, instead stressing that shipbreaking activities discharge the major share of pollutants and create an unacceptable stream of toxic waste, itself a contested claim rendered more stable by the discursive framing and leveraging work done by NGOs to position the problem as a local issue for the purpose of global strategy. On the other hand, yard owners reiterate that "no one wants to throw money into the water", invoking the cultural practice of waste use, nullifying the NGOs frame.

\subsection{Worker Safety Issues: Frames and Counter Frames}

In addition to concerns about environmental degradation, NGOs express concern over the treatment of workers in the shipbreaking yards. An interviewee from a local NGO stated:

The ways the workers are treated in the yard are not humane. They [the yard owners] do not consider them as human. They are abusing these people as they do not get work. Does that mean that we will allow them to die? How can a man remain indifferent to the high number of casualties? It is their mentality that is rotten. They [yard owners] are no longer human; they hunger after money. They profit from the savings that they have to spend for workers training, medical treatment and others. Day by day the accidents are increasing and so are the deaths. We have our documents, please take them; we have documented all workers who died of accidents. Of course the available information we have, we do not have the lists of all casualties, and the actual number is even higher. 
The NGO official presents an economic argument focused on securing profit and points to yard owners as the problematized actors; this discourse emerges as a result of a "risk-averse" framing in which life is priceless and it is essentially immoral to associate life loss with money. An inferred problem that no actor (including the NGOs) has yet made explicit is the standard for safety. How many industrial deaths are okay in Bangladesh? To what standard should the Bangladeshi shipbreaking industry be compared? Other industries in Bangladesh, or shipbreaking in other countries? These questions are arguably excluded by the NGO discourse and instead, NGO framing stresses the power of documentation of casualties and indicates the situation is worse in shipbreaking than in other industries, although without explicitly comparing to other industries to support the discursive frame.

An official from the DoE tasked with supervising shipyards expressed a different narrative: "This industry has opened my eyes. I have this layman idea that this industry is a bad industry, but when I actually visited during my field training in the yard I found that this industry is developed and has become, I would say, semiautomatic." Recent technologies have been introduced to the yards, which could be improving worker safety; for example, magnetic grabs and cranes have been used since 2005 and carry heavy loads (Figure 1). Yard officials often raise the point of the introduction of magnetic grabs as a defense against high worker injury rates touted by NGOs, yet these grabs also increase profits (by lowering the number of workers needed), which aligns with the NGOs claims of the primacy of economic profits in yard owner decision-making. As one yard owner explained, "the grab speeds up our work and reduces worker involvement. Look, now we dismantle a ship of 10,000 tons in one month but this would take six months when we did not have this. We have workers reduced by about half by this grab." While visiting the yards and conducting interviews, LA witnessed the grabs in near-constant use. Thus, another unanswered question remains: as automation reduces worker safety issues, and reduces the number of workers, how are these aspects of development viewed through the differing perspectives of these actors, especially workers?

In a tour of a yard, one participating yard manager showed off the workers' dormitories with multiples stories, where they sleep at night and have access to a dining room and kitchen where they eat and cook. This yard manager discussed both improvements to worker safety from new equipment and the opportunities for yard workers relative to other local employment. When asked why yards have restricted entry, he mentioned rent-seeking [bribery] activities of local reporters. He said,

Most of the local reporters are not well educated and ... they work unpaid. They bully us whenever there is an accident, they demand money from us, even the local police demand money from us. If we do not give money, they inflate the news ... Look at these workers are working. What risk do you find in there? Okay, we have accidents, but tell me where is accident free. Please go the police station ... and ask the report of people killed in road accidents every day. I am sure the casualties are a hundred times more than us. Why do they report on accidents, why do they not report on employment? How many people do we employ, where do you get the steel made from these scraps?

This yard manager consistently relied on contextualizing the issue, invoking the general problem of lacking employment opportunities in Bangladesh. It seems that yard owners seemed more interested in "life saved or accidents prevented and that the yard is improving" (Dey 2016). Regarding safety clothes, one yard manager said that "they have all of the clothes available but the workers cannot work long hours wearing them because they are heavy and make them tired".

The reality is that Bangladesh placed in the fourth quartile among the most corrupt countries, and the problem the yard owner indicates reflects that fact (Transparency International 2017). Yet, yard owners also consider NGO documentation a form of rent-seeking. Yard officials orient their discourse surrounding worker safety to two external contexts: socio-institutional corruption practices and working conditions across the country. Behind the discourse, yard officials seem to insinuate a consistent scale association to the national level, a salient example of scale politics. One of the NGO respondents claimed that yard owners "manage to throw dead bodies to the sea" to indicate 
the yard owners' tendency to maintain poor working conditions by resorting to and benefitting from the corrupt context of Bangladesh. In addition, the claim also represents institutional contexts, which is indicated in one yard owner's comments about inspection that "the inspection teams lack expert personnel, infrastructure, necessary technologies that can measure the level of oxygen availability, presence of toxic fumes for hot work". He added, "we apply our own technique of introducing "healthy chicken' to understand the availability of oxygen inside." This institutional context is referenced by NGOs in different terms: "shipbreaking industry is fragmented in multiple ministries in Bangladesh and when you are divided into three institutions, you are actually under none of them."

\subsection{Scale Configuration of Actors}

NGOs construct the shipbreaking phenomenon as a space of dependence, and have built a knowledge network with international NGOs that depends on local knowledge produced by local NGOs. For example, in 2006, YPSA released a report on the shipbreaking industry in Bangladesh in collaboration with researchers from the Institute of Marine Science, University of Chittagong (Hossain and Islam 2006). NGO officials served the role of field coordinator for the NGO Shipbreaking Platform and collaborated with International NGOs such as FIDH, Greenpeace, and others to publish reports related to worker deaths and accidents (YPSA 2017). Exposure via international media outlets (BBC, CNN) and national newspapers (The Daily Star, Bangladesh) represents a systemic form of discursive strategy (Foucault 1980). Hillier (2009) stresses how regular press releases packed with legal information and rhetorical statements published on NGO websites are regularly cited in local, national and international media, producing "Habermasian aspects of systematic distortion of communication". Local NGOs maintain strong international networks to create knowledge that conforms to the expectations of international stakeholders. The funding dependency of the local and national NGOs on international organizations determines their scale and focus. As one government official stated, "Why do the NGOs work? Who funds the NGOs? Please investigate the matters; you will see that most of the projects are internationally funded." The official of one NGO concurred with this perception of their funding stream: "It is hard to say exactly how much of our projects are externally funded, but mostly are from US, EU, Japan and others. Almost 60 percent are from abroad and some $20 \%$ are nationals and the rest are our own." In an RT documentary on shipbreaking, an NGO official acknowledged that he gets funding from an EU project to work on this issue (RT Documentary 2017), thus demonstrating the influence of international perspectives on this local issue.

Local NGOs draw power resources from international networks, a process that arguably shapes the discursive framing of shipbreaking in ways that aim to leverage additional resources. In contrast, yard owners seem to rely on power derived from local political involvement, specifically through positions in party politics. Security personnel at the gate of a yard mentioned to me, "we do not have ships now; we had ships during previous government, now we are waiting for the government to change." They later explained that the yard owner he works for belongs to the opposition political party that causes the decline of business. This also indicates that a power mechanism due to party affiliations reigns over issues of non-compliance, undermining the institutional and legal obstacles that bring more ships, ensuring profit. A local newspaper recently reported that two yards, whose owners were parliamentarians in the previous government, were demolished because 15,000 trees were cut to establish the yard-an example of unusual power involvement in how the yards are managed (Figure 3, (The Daily Star 2014), YPSA website accessed on 23 January 2015). A newspaper report shows that most yards are owned by someone active in local/national politics (The Daily Star 2014). A RT documentary shows that Chittagong City Council Mayor owns a yard and he did not like to talk about the yard (RT Documentary 2017). The yard owners' power, although it lies at the national and local scale and is based on which party is in power, is more direct and focused. Conversely, through their linkages with international NGOs, local NGOs exert only indirect pressure by publishing papers and reports (Freudenburg 1993). This may provide an answer as to why the yard owners do not bother to mobilize an alternative discourse that counters the NGOs discourse. 


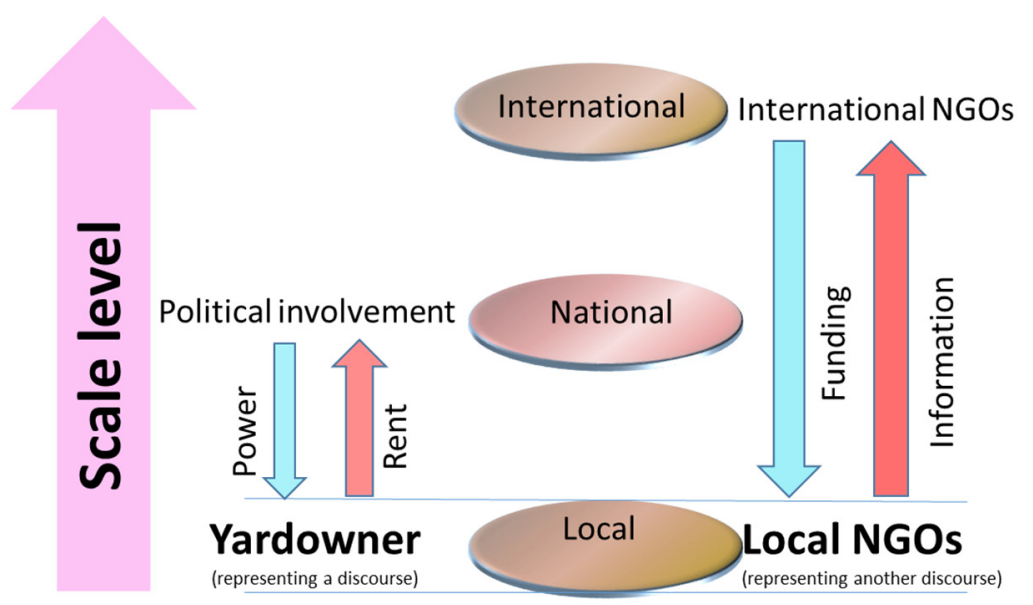

Figure 3. Yard owner and local NGOs scale association in Bangladesh shipbreaking industry.

\subsection{Workers' Position}

The workers' responses seemed to suggest a rather nuanced understanding of the balance between economic opportunity and worker safety. They described the work as hard but at the same time they were happy as each incoming ship would employ them for a few more months. When asked if they had any stress related to their work from the yard owners or officers, most workers expressed ideas similar to one worker who said, "No. We take our time; they do not even ask what we are doing. We are relaxed here." One cutter man responded, "I work based on my will. When I feel good, I work even fifteen hours at a stretch. If I do not feel like working, I do not come to work even for the whole week." Another cutter man, who had been working for two years, said, "I worked all night last night and today won't go to work. I work two months then go back to my village and rest for one month and come back. What we earn I give to my family and then come back. This is the kind of work that you cannot continue for long." One worker, found sitting in the yard resting, and said that he had a small injury in his leg and pain. When asked if anyone would punish him as he was sitting instead of working, he said, "The yard people do not force cutters to work as we are paid according to how much we work. They have nothing to do with me." Another worker said, "in our yard we work only eight hours from 8:00 a.m. to 4:00 p.m., we cannot work for long times, on an average, a worker works 10-15 years, but most do not. I try to save money so that I can invest in my village."

One interview was completed with a group of workers working at the bottom of a large ship. When asked if they find this work risky, one of the workers said, "Work here is as risky as the work outside. I have been working here for about five years and now I know what to do. If I am not careful while I am working, I may fall down or a plate may fall on me. When you come for the first time, you do not know what is going on but as the time goes by, people get to know how to deal with these things." I asked if he saw anyone killed or injured, and he said, "I hear about people injured and killed, but I have never seen anyone killed since I have started this work." When asked if anyone in his group has suffered injuries, he said, "Injury is nothing, this is iron and you deal with that. So you will get cut almost every day, that is normal. However, thank God, none died in our group since we are working together." He added that, "I get about 500 taka (about 6.5 USD) a day but this is high for me as I am a skilled worker but, he (a man standing beside him) gets somewhere around 300 taka (4 dollars). Where I would get this much? Moreover, if you are a day laborer outside, you may have work today, then you do not have work tomorrow." In the yards, most workers are contract workers. About half of the cuttermen are contracted by the businessmen who have already purchased scraps and need the scraps cut into smaller sections; the businessmen bring workers into the yard and pay by the job. The work injuries and accidents suffered by the cuttermen are unrelated to the work of the yard owners and managers. The workers who work for the yard are supervised by a 
foreman, who is responsible for managing workers. Foremen mediate the economic transaction with yard owners and workers. This contract arrangement distributes some of the liabilities through these middle businessmen, relieving yard owners themselves from the direct consequences.

\section{Discussion}

The findings demonstrate that four stakeholders broadly constitute the shipbreaking discourses - the yard owners, the workers, the NGOs and the Government [GOs hereafter]. The interests of two parties are easily summarized: the owners wish to maximize their profits/wealth and the workers wish to do the same with their income and preferred work against the low employment opportunity. While the owners are expected to know and follow their interest, this is not necessarily so for the workers. In contrast, the owners seem to exploit the conditions while keeping political connection to secure profit base. The NGOs wish to represent the workers, based on the belief that the workers are either incapable of understanding, or unable to pursue, their own interests. Finally, the GOs support the yard owner discourses, which may be summarized as preferences over development to environment.

The role of profits or profit mentality played a crucial role in how discourses are framed. As explained by a manager, the profits are highly uncertain. Hence the more that by-products can be commercialized, the better all interests are served. The introduction of technology also enhanced profitability for the yard officials and serve as a defense to NGO discourse. It is not clear that the introduction of technology is driven by NGO discourse or yard owners' profit motive. However, technology dedicated for loading replaces the need for workers and hence reduces employment. The GOs seem to support improvement discourses due to partially the connection with party politics that articulates the agreed position, although yard officials blamed GOs for underutilizing tax money to improve institutional facilities.

\subsection{Theoretical Connections for Workers' Positions: Worker Interest and Risk Preferences}

The workers' position demonstrates three broad points, regarding risk nature, risk contexts and risk calculation. By risk nature, the workers invoke ideas such as hard work, but also relaxation, and injury essentially communicates the dangerous nature of work environment. By risk context, the workers mention the tropical climate and that risk as being everywhere and they invoked the idea of "self-management of safety equipment", which illustrates the reliance on available information that shapes their choice. The workers also indicate their way of risk calculation by discussing money, carefulness, and opportunity for temporary leave. This relates to Douglas and Wildavsky's (Douglas and Wildavsky 1983) "state of society assumptions", meaning that the workers often have calculative assumptions and that the discourse that excludes such assumptions carries only "trivial information or hilarious inconsequentialities" (p. 81).

The tropical climate that inhibits the use of safety clothes and the lack of willingness to spend money on safety equipment must be understood from the "embodied capacities in the performances of tasks in social context" (Adger et al. 2001). Discourse driven by NGOs is "rarely understood by their [workers] own terms ... [and] serves western style bio-imperialism" (Escobar 2011, p. 170). Arguably, the emphasis on workers' rights is driven by the empathy of first world institutions (and in this case, third world NGOs sharing a first world view), identifying "the other whose sorrows and frustrations are being made part of the spectacle" and thus are viewed as a false cultural affirmation (Escobar 2011, p. 170). This does not mean that the workers are immune from sorrow and frustrations, but rather that the priority of the workers is misrepresented and "intentionally uninformed" (Leach and Mearns 1996; Peluso et al. 1994). The difficulty of understanding such a paradoxical stance of workers and their representation of sufferings needs to be studied "against the exploitation of and domination over the conditions of local, regional, national and global political discourses" (Escobar 2011).

In 2009, court-led directives resulted in the suspension of yard activities. Workers participated in a protest against the suspension order. BELA claimed that yard owners scared workers into 
participating in the protest. One respondent from BELA officials and later joined as a judge stated, "we must prioritize the environment and that the economy and development will follow afterwards. There are ways to meet iron demand, probably importing. But workers cannot be put to death". Our interviews with workers suggest that workers value their employment in shipbreaking (Cairns 2014). This contradiction is reminiscent that peasants have their own culture, needs preferences and demands that are most often determined by the access to available opportunities (Peluso et al. 1994; Buerk 2006). Buerk (2006) ethnography of the shipbreaking industry in Bangladesh captured how workers recalled their helplessness-potentially exhibiting risk takers behaviors-over the abysmal economic plights their families experienced. He stated, "Young men ... hung around all day ... not much hope of finding any [work] in the fields or village shops" (pp. 76-78). The perspective of workers on the risks and benefits of shipbreaking work are thus influenced by "choices of survival and necessities rather than life style and choice," (Cairns 2014). This reflects the position of risk framing of workers-one desperate for money and employment—contrasted with the other discourses that have different risk framing—sanctity and pricelessness of life.

\subsection{Discursive Framing}

This study illustrates three aspects of discursive framings. First, discursive framings epitomize narratives that represent "temporary fixity" (Hillier 2009) or "fragmentation or stretching" (Hillier 2009), highlighting selective elements of the stories while obscuring other relations (political connections), processes (rent seeking) and contexts from the discourses. This selectivity or style of discursivity involving inclusion (documentation of accidents) or exclusion (cultural contexts), presence (pollutant from ships) or absence (pollutions from elsewhere) gives ways to scale politics, situating narrative(s) in a particular scale that favors. This "temporary fixity/selection travels, transforms (gets transformed) and re-inscribes (gets reinscribed) through sites of multiple knowledge power constellations and bolsters "accepted wisdom" as in the case of scientific production regarding pollution assessment (Ferree 2002). As Escobar (1998) mentioned, globalocentric biodiversity prescribes a certain representation pertaining to "threats" (p. 56). Second, discourse also generates spaces and sensation. For example, an end of life ship produces "bloc(s) of sensation" to its associated actors with opportunity to NGOs (through association of international projects on shipbreaking), fear and optimism to workers (works are risky, works bring money), and weary to yard owners (political bondage buffering injury and accidents, uncertainty to market behavior affecting profit). This is reminiscent of the multiplicity of spaces that a ship creates beyond the essential materiality of ships: "pollutants" "accidents", "profit", "waste", "contexts" and "toxicity". All of these catchphrases are dead phenomena, only alive with actors' representations and acquire meaning that transcends through human (actors, networks) and non-human (websites, media, scientific studies) interventions. Third, the discourse often represents "messiness of interaction" with no central power that has sufficient control and competence to govern the activities (also consequences). For example, yard owners' political influence may not control the image construction derived from international communications of NGOs and vice versa.

\subsection{Scale Politics and Risk Framing}

Disputes over the different discursive framings in the shipbreaking phenomenon arguably originate from different spaces of engagement via associated networks at different scales. The power derived from political involvement among yard owners is reflected at the local scale through party politics, while the power of NGOs operates only through indirect pressure through international linkages (Gerber 2011). According to Foucault (1980), effects of power have two major manifestations: one is a productive network that traverses and produces things, induces forms of knowledge and produces discourses, and the other is in the form of repression characterized as forced tolerances (entry restriction, accident information suppression) and costly ostentation (security personnel) (p. 119). The former penetrates slowly but continuously and is more efficient and less wasteful than the latter 
that applies spectacular and discontinuous interventions of power (Foucault 1980). Appearing at media, coordinating the production of scientific data, and the political effect of the scientific production representing space of engagement at international level through superior productive structure, not because the content is scientifically standardized but because of the governing and coordinating structure. Foucault (1980) stated that the power does not only underlie in theoretical form (systematic ensembles) or in the dictation of it, but also who governs the statements and how the statements are governed each other matters. By saying this, he meant that it is less important to know what external power imposes on science but more of knowing what effects of power permeate the scientific statements. The governing thus produced imposes acceptability, not just the measurement of it and thus, is highly powerful (Foucault 1980).

How does the yard owners' space of engagement with direct form of power, not so much on discourses, work as an anti-effort to knowledge power constellations? Is it a discourse altogether? Foucault (1980) realized the existence of non-discursive practices that form the term "dispositive", which is a heterogeneous ensemble of discursive and non-discursive practices (regulations, laws, institutions and administrative measures etc.). Yard officials strategically take advantage of non-discursive strategies i.e., structural (contracting arrangements of workers, poverty), institutional (lack of skill and inspection team, providing workers amenities) and environmental (tropic climate references), and not so much of discursive ones, such as knowledge generation and publication, information networking and media exposure as NGOs (Rhodes 2016). This dispositive represents a strategic function that applies in an urgent response (for example political effect through demonstration incorporating workers against court ruling) (Jäger 2001). Yard owners' dispositive is also emblematic in the long-term existence of shipbreaking industry. The space it creates through contingent businesses (secondary processing, national resources support) and socio-cultural contributions appropriate locally (local business support and secondary consumers) provides a materialistic support base over the years (Andsager 2000; Kurtz 2003; Gregson et al. 2010, 2012; Frey 2015; Rahman and Mayer 2015). It is interesting to see if this dispositive, meaning the combination of less discursive and more non-discursive elements, can sustain against the NGO discursive strategies. A Foucauldian paradigm is suggestive in adding more discursive strategies to the yard owners' dispositive.

An interesting theoretical contention exists in the determination of the presence of "accepted wisdom" and "truth" in different strands of discourses. Do we understand the representative strands of discourse as true or false? Or do we rest upon the interactive patterns of the discourses that lead to eventual closeness to the reality? Foucault (1980) is less interested in drawing lines between the discursive and dispositive as true false dichotomy, and more interested in seeing how historic effects of truth are produced within discourses that are neither true nor false (Foucault 1980). He suggested that the key aspect of the discourses is to look for the urgency that the discourse exerts to identify trivials (other sources of pollution, rent seeking, short speech delivery in media, business decline with political change) and chance occurrences (finding other industries for pollutant discharge, dead body hiding), which he termed as event. In searching event, he emphasized being a non-structuralist who tends to locate different types of events in different levels differing in amplitude, chronological breadth and capacity to produce effects (Foucault 1980). For example, identification of all pollution sources and business decline as a trivial event has scale references, temporality (the effects of it being long and short), and a network associated to it. Similarly, rent-seeking and media exposure as chance occurrence signify how discourses shape and are shaped by the spaces of engagement across the scales (Cox 1998; Swyngedouw and Heynen 2003; Harris and Alatout 2010).

\subsection{Policy Implications}

Successful policy must be undertaken at the appropriate scale; discourse that obscures the appropriate scale can thus inhibit appropriate actions and encourage ineffective ones. For example, consider the policy intent to reduce marine pollution. The direct consequence of the local scale emphasis is, first of all, that the other industries continue to freeride and enjoy immunity to pollute 
and that the policy makers continue to divert economic and intellectual resources from them. Second, additional level of complexity in designing the national level of policymaking continues to be elusive in the local level focus. In this study, understanding how each type of industry contributes to the contamination of coastal waters necessarily shifts the concentration from an industry-specific scale (e.g., shipbreaking industry) to a wider geographical scale, which forces stakeholders to include holistic system variable such as institution, culture and ideology. Note that the decision regarding an appropriate standard of worker safety is also inherently a national issue (Devault et al. 2017), but one that has been inappropriately applied to the industry scale (resulting in inconsistencies across industries). For example, a policy focus on the metal cutting stages of production will make the largest impact reduction, while a singular focus on solid and liquid wastes in the shipbreaking yards, as represented in NGO discourse, is not likely to bring about the large reduction in environmental contamination (Rahman et al. 2016). Third, a general tendency is emerged that leads to "agreed conclusions" or "accepted wisdom", manifested in pollution assessment focus on scientific literature and excludes parts of other discourses, attended in the local community experiences (shopkeepers and fisherman) (Leach and Mearns 1996).

\subsection{Implications of Scale Distortion}

In addition, scientific publications and technological introduction embody and settle in a particular institutional, normative and political context, thereby have scalar repercussions (Foucault 1980; Leach and Mearns 1996; International Maritime Organization 2016). This "accepted wisdom" from dominating discourses influences how policy is formulated. The 2011 Ship Breakers and Ship Recycling Rules (SBSR Rules 2011) is intended to improve the yard situation through inspection, certification and punishment for non-compliance (Freudenburg 1993), based on pollutant threats and its alleged source-shipbreaking-demonstrating subscription to the NGO led discourse. These policy outcomes disregard consideration of the institutional and cultural framework (corrupt practices, working behavior, rent seeking, etc.) and the political affiliations of actors that inspire corrupt practices. Even the (national) policy makers themselves do not subscribe to high standards for environment and working conditions for only one specific industry (Rahman and Mayer 2016).

The International Maritime Organization (IMO) launched a project (Programme No. TC/1514 SENSREC" Safe and environmentally sound ship recycling in Bangladesh-Phase I) based on the constructed discursive framing of shipbreaking as polluting and dangerous, leading to a report titled, "Evaluation of environmental impacts of ship recycling in Bangladesh", which reflects the priority placed on industry specific scientific pollution data (International Maritime Organization 2016). However, the narrow focus is redressed by the evaluation of the pollution discharged throughout the region in work package 2. Clearly, the introduction of work package 2 considers the wider pollution contexts-an example of how appropriate scale thinking can improve significantly in project planning and implementation.

\section{Conclusions}

This study finds that "political mobilization in populations exposed to technological hazards are far from unified" and illustrates how "socio-natural injustices at particular scales do not necessarily translate into injustices at other scales" (Kurtz 2003, p. 783). The politics with the risk acceptance of workers represent discursive islands with high elasticity (risk averse vs. risk taker framing) with the change of actors and creates continuity for injustice i.e., spatio-temporally static documentation of accidents and injuries, emblematic of Bolivian soil loss discourses (Peet and Watts 1996). Similarly, wider natural environmental and occupational environmental contexts are referred/emphasized (curtailed) with the assessment of pollutions and working conditions by actors. This demonstrates supposedly endless sets of possibilities that are underpinned by multiple forms of contested knowledge-power constellations, sheltering to spaces and politics and constructing risk acceptability for workers (Leach and Mearns 1996; Escobar 1998; Cox 1998; Marston 2000). 
That may result in "increased social inequalities, degraded ecosystems and amplified overall exposure to extreme events" if proper attention is not paid to "strategic deployment of scale" by actors (Cairns 2014; Rhodes 2016, p. 544). Thus, scientists networking with NGOs, political affiliation of yard owners and local NGOs participation in national and international media outlets represent a multi scalar network embodying a process of scalar structuration through continuous deployment of labor and resources to forge a political playground of constructing reality (Kaiser and Nikiforova 2008; Bickerstaff and Agyeman 2009). Here Escobar (2011) aptly suggested to avoid any of extremes and devise ways of embracing alternatives, while recommending not to turn away eyes from the capitalist hegemony.

Thus, shipbreaking becomes a case for politics in which NGOs tend to establish unacceptability and yard officials to focus reasons for acceptability (Douglas and Wildavsky 1983). Locally experienced sources of pollution and worker risk acceptance become a politico-economic relation(s) and process(es) distributed across far reaching spatial networks creating "space of engagement" (Bickerstaff and Agyeman 2009; Swyngedouw 2000, p. 784). The space of engagement situation may be linked to "backward relations of domination" as Escobar (2011) termed it or a direct form of repressive power as Foucault (1980) suggested. In both cases, the discourses seem to victimize the workers. The risk unacceptability notion (with the image of shouldering practice) seems to suggest a worker-alienating technological introduction that, largely, is geared toward the modern capitalist sector, throwing workers deep into the vicious cycle (Swyngedouw and Heynen 2003; Cairns 2014). That sets the basis of workers' risk acceptability notions, which themselves are responsible for supporting the direct form of repression, not acknowledged in any of the discourses addressed but highlighted in Cairns (2014). Thus, all actors more or less contribute to the system of the construction of the "space of engagement" and the associated scale politics.

This research invokes humancentric understanding of end-of-life ship dismantling politics, applying discursive theories in order to understand interconnectedness of discourse, knowledge and power that informs the political ecology research and contributes to the literature that applies discursive political ecology research in less developed countries (Escobar 1998). This study-to the best of my knowledge-is the first that deploys discursive theory, highlighting shipbreaking as a contested "space(s) of dependence" that is simultaneously negotiated, contested, curtailed and substantiated through space of engagement at different scales, yet such stability is far from creating a "clear and transparent" reality (Cairns 2014). In addition, this study shows that the social knowledge (and the accompanied responsibility of appropriate application) should not be based on a crude empathy that implies notions of acceptability for other sorrows. Rather, this should permit access to the other point of view and be aware of the intent of broader exploitation as well as cultural affirmations (Escobar 1998, 2011). The successful policy formulation comes out of combining elements of these two discourses (Foucault 1980; Escobar 2011). The usefulness of this study is that the stakeholders will be more conscientious of their position and, therefore, be cognizant of the merits of the opposing discourses, leading to identification of common ground for collaboration and cooperation. Our contention is that these diverse discursive framings and articulation of scalar arrangements lacked due attention from policy makers, both national and international, which preclude thorough understanding of and formulating of the policy for shipbreaking in all relevant scales. This research can be a basis for further inquiry of avoidable risk elimination by yard officials, GO participation in improvement and cost allocation for risk avoidance. This study will also bring attention to micro-level ideological and strategic conflict in the environmental field and will ignite discussion of already settled discourses in other sectors of the developing world at large and Bangladesh in particular.

Author Contributions: Mizanur Rahman, Audrey Mayer, Chelsea Schelly and Emma Norman conceived and designed the study; Mizanur Rahman performed the field visits and data collection; Mizanur Rahman, Chelsea Schelly, Emma Norman and Audrey Mayer analyzed the data and wrote the paper.

Conflicts of Interest: The authors declare no conflict of interest. 


\section{References}

Abdullah, Hasan Muhammad, M. Golam Mahboob, Mehmuna R. Banu, and Dursun Zafer Seker. 2013. Monitoring the Drastic Growth of Shipbreaking Yards in Sitakunda: A Threat to the Coastal Environment of Bangladesh. Environmental Monitoring and Assessment 185: 3839-51. [CrossRef] [PubMed]

Adger, W. Neil, Tor A. Benjaminsen, Katrina Brown, and Hanne Svarstad. 2001. Advancing a Political Ecology of Global Environmental Discourses. Development and Change 32: 681-715. [CrossRef]

Andersen, Aage Bjørn. 2001. Worker Safety in the Ship-Breaking Industries. An Issues Paper. Geneva: The International Labour Office.

Andsager, Julie L. 2000. How Interest Groups Attempt to Shape Public Opinion with Competing News Frames. Journalism \& Mass Communication Quarterly 77: 577-92.

Bailey, Paul J. 2000. Is There a Decent Way to Break up Ships? ILO Discussion Paper; Geneva: ILO.

Benford, Robert D. 1993. You could be the hundredth monkey. The Sociological Quarterly 34: 195-216. [CrossRef]

Bickerstaff, Karen, and Julian Agyeman. 2000. Framing Processes and Social Movements: An Overview and Assessment. Annual Review of Sociology 26: 611-39.

Bickerstaff, Karen, and Julian Agyeman. 2009. Assembling Justice Spaces: The Scalar Politics of Environmental Justice in North-east England. Antipode 41: 781-806. [CrossRef]

Brown, J. Christopher, and Mark Purcell. 2005. There's nothing inherent about scale: Political ecology, the local trap, and the politics of development in the Brazilian Amazon. Geoforum 36: 607-24. [CrossRef]

Buerk, Roland. 2006. Breaking Ships: How Supertankers and Cargo Ships are Dismantled on the Beaches of Bangladesh. Los Angeles: Chamberlain Brothers.

Cairns, George. 2007. Postcard from Chittagong: Wish You were Here? Critical Perspectives on International Business 3: 266-79. [CrossRef]

Cairns, George. 2014. A critical scenario analysis of end-of-life ship disposal: The "bottom of the pyramid" as opportunity and graveyard. Critical Perspectives on International Business 10: 172-89. [CrossRef]

Charmaz, Kathy, and Linda Liska Belgrave. 2007. Grounded Theory. New York: John Wiley \& Sons, Ltd.

Cox, Kevin R. 1998. Spaces of Dependence, Spaces of Engagement and the Politics of Scale, or: Looking for Local Politics. Political Geography 17: 1-23. [CrossRef]

Crang, Mike. 2010. The Death of Great Ships: Photography, Politics, and Waste in the Global Imaginary. Environment and Planning A: Economy and Space 42: 1084-102. [CrossRef]

Crotty, Michael. 1998. The Foundations of Social Research: Meaning and Perspective in the Research Process. Thousand Oaks: Sage.

Demaria, Federico. 2010. Shipbreaking at Alang-Sosiya (India): An Ecological Distribution Conflict. Ecological Economics 70: 250-60. [CrossRef]

Devault, Damien A., Briac Beilvert, and Peter Winterton. 2017. Ship breaking or scuttling? A review of environmental, economic and forensic issues for decision support. Environmental Science and Pollution Research 24: 25741-74. [CrossRef] [PubMed]

Dey, Arun Bikash. 2016. Life at Death Yard. Available online: http:/ / www.thedailystar.net/frontpage/life-deathyard-202612 (accessed on 26 July 2017).

Douglas, Mary, and Aaron Wildavsky. 1983. Risk and Culture: An Essay on the Selection of Technological and Environmental Dangers. Berkeley: University of California Press.

Doulton, Hugh, and Katrina Brown. 2009. Ten years to prevent catastrophe? Discourses of climate change and international development in the UK press. Global Environmental Change 19: 191-202. [CrossRef]

Escobar, Arturo. 1998. Whose knowledge, whose nature? Biodiversity, conservation, and the political ecology of social movements. Journal of Political Ecology 5: 53-82.

Escobar, Arturo. 2011. Encountering Development: The Making and Unmaking of the Third World. Princeton: Princeton University Press.

Ferree, Myra Marx. 2002. Shaping Abortion Discourse: Democracy and the Public Sphere in Germany and the United States. Cambridge: Cambridge University Press.

Fiss, Peer C., and Paul M. Hirsch. 2005. The Discourse of Globalization: Framing and Sensemaking of an Emerging Concept. American Sociological Review 70: 29-52. [CrossRef]

Foucault, Michel. 1980. Power/Knowledge: Selected Interviews and Other Writings, 1972-1977. New York: Pantheon. 
Freudenburg, William R. 1993. Risk and recreancy: Weber, the division of labor, and the rationality of risk perceptions. Social Forces 71: 909-32. [CrossRef]

Frey, R. Scott. 2015. Breaking Ships in the World-System: An Analysis of Two Ship Breaking Capitals, Alang-Sosiya, India and Chittagong, Bangladesh. Journal of World-Systems Research 21: 25. [CrossRef]

Gerber, Julien-François. 2011. Conflicts over industrial tree plantations in the South: Who, how and why? Global Environmental Change 21: 165-76. [CrossRef]

Gregson, Nicky. 2011. Performativity, Corporeality and the Politics of Ship Disposal. Journal of Cultural Economy 4: 137-56. [CrossRef]

Gregson, N., and M. Crang. 2010. Materiality and Waste: Inorganic Vitality in a Networked World. Environment and Planning A: Economy and Space 42: 1026-32. [CrossRef]

Gregson, Nicky, Mike Crang, Farid Ahamed, Nargis Akhter, and Raihana Ferdous. 2010. Following Things of Rubbish Value: End-of-life Ships, 'Chock-Chocky' Furniture and the Bangladeshi Middle Class Consumer. Geoforum 41: 846-54. [CrossRef]

Gregson, Nicky, Mike Crang, Farid Uddin Ahamed, Nasreen Akter, Raihana Ferdous, Sadat Foisal, and Ray Hudson. 2012. Territorial Agglomeration and Industrial Symbiosis: Sitakunda-Bhatiary, Bangladesh, as a Secondary Processing Complex. Economic Geography 8: 37-58. [CrossRef]

Hannigan, John. 2006. Environmental Sociology, 2nd ed. London: Routledge.

Harris, Leila M., and Samer Alatout. 2010. Negotiating hydro-scales, forging states: Comparison of the upper Tigris/Euphrates and Jordan River Basins. Political Geography 29: 148-56. [CrossRef]

Hillier, Jean. 2009. Assemblages of justice: The 'ghost ships' of Graythorp. International Journal of Urban and Regional Research 33: 640-61. [CrossRef]

Hossain, Maruf Md M., and Mohammad Mahmudul Islam. 2006. Ship Breaking Activities and Its Impact on the Coastal Zone of Chittagong, Bangladesh: Towards Sustainable Management. Chittagong: Advocacy \& Publication Unit, Young Power in Social Action (YPSA).

Hossain, M. Shahadat, Sayedur R. Chowdhury, S. M. Abdul Jabbar, S. M. Saifullah, and M. Ataur Rahman. 2008. Occupational Health Hazards of Ship Scrapping Workers at Chittagong Coastal Zone, Bangladesh. Chiang Mai Journal of Science 35: 370-81.

International Maritime Organization. 2016. Evaluation of Environmental Impacts of Ship Recycling in Bangladesh Final Report. Programme No. TC/1514 "SENSREC" Safe and Environmentally Sound Ship Recycling in Bangladesh—Phase I. December. Available online: http://www.imo.org/en/OurWork/Environment/ SupportToMemberStates/MajorProjects/Documents/Ship\%20recycling/WP1b\%20Environmental\% 20Impact\%20Study.pdf (accessed on 13 July 2017).

Jäger, Seigfried. 2001. Discourse and knowledge: Theoretical and methodological aspects of a critical discourse and dispositive analysis. Methods of Critical Discourse Analysis 1: 32-63.

Kaiser, Robert, and Elena Nikiforova. 2008. The performativity of scale: The social construction of scale effects in Narva, Estonia. Environment and Planning D: Society and Space 26: 537-62. [CrossRef]

Kibria, Golam, Md Maruf Hossain, Debbrota Mallick, T. C. Lau, and Rudolf Wu. 2016. Monitoring of metal pollution in waterways across Bangladesh and ecological and public health implications of pollution. Chemosphere 165: 1-9. [CrossRef] [PubMed]

Kurtz, Hilda E. 2003. Scale frames and counter-scale frames: Constructing the problem of environmental injustice. Political Geography 22: 887-916. [CrossRef]

Leach, Melissa, and Robin Mearns. 1996. The Lie of the Land: Challenging Received Wisdom on the African Environment. London: James Currey Ltd.

Lebel, Louis, Po Garden, and Masao Imamura. 2005. The politics of scale, position, and place in the governance of water resources in the Mekong region. Ecology and Society 10: 18. [CrossRef]

Litfin, Karen. 1994. Ozone Discourses: Science and Politics in Global Environmental Cooperation. New York: Columbia University Press.

Marston, Sallie A. 2000. The social construction of scale. Progress in Human Geography 24: 219-42. [CrossRef]

Mitchell, Timothy. 1991. Colonising Egypt. Berkeley: University of California Press.

Norman, Emma, Karen Bakker, and Christina Cook. 2012. Introduction to the themed section: Water governance and the politics of scale. Water Alternatives 5: 52-61.

Peet, Richard, and Michael Watts, eds. 1996. Liberation Ecologies: Environment, Development, Social Movements. London: Routledge. 
Peluso, Nancy Lee, Craig R. Humphrey, and Louise P. Fortmann. 1994. The rock, the beach, and the tidal pool: People and poverty in natural resource-dependent areas. Society $\mathcal{E}$ Natural Resources 7: 23-38.

Rafey, William, and Benjamin K. Sovacool. 2011. Competing discourses of energy development: The implications of the Medupi coal-fired power plant in South Africa. Global Environmental Change 21: 1141-51. [CrossRef]

Rahman, S. M. Mizanur, and Audrey L. Mayer. 2015. How Social Ties Influence Metal Resource Flows in the Bangladesh Ship Recycling Industry. Resources, Conservation and Recycling 104: 254-64. [CrossRef]

Rahman, S. M. Mizanur, and Audrey L. Mayer. 2016. Policy compliance recommendations for international shipbreaking treaties for Bangladesh. Marine Policy 73: 122-29. [CrossRef]

Rahman, S. M. Mizanur, Robert M. Handler, and Audrey L. Mayer. 2016. Life cycle assessment of steel in the ship recycling industry in Bangladesh. Journal of Cleaner Production 135: 963-71. [CrossRef]

Rhodes, Carl. 2016. Democratic business ethics: Volkswagen's emissions scandal and the disruption of corporate sovereignty. Organization Studies 37: 1501-18. [CrossRef]

Ritchie, Jane, and Liz Spencer. 2002. Qualitative data analysis for applied policy research. The Qualitative Researcher's Companion 573: 305-29.

Robbins, Paul. 2011. Political Ecology: A Critical Introduction. New York: John Wiley \& Sons, vol. 16.

RT Documentary. 2017. Scrapped: Shipbreaking Cutters. Available online: https://www.youtube.com/watch?v= fqrRhqv0Iw (accessed on 13 July 2017).

Said, Edward. 1979. Orientalism. New York: Vintage.

Saraf, M., F. Stuer-Lauridsen, M. Dyoulgerov, R. Bloch, S. Wingfield, and R. Watkinson. 2010. The Shipbreaking and Recycling Industry in Bangladesh and Pakistan. Washington: World Bank.

Sharifuzzaman, S. M., Hafizur Rahman, S. M. Ashekuzzaman, Mohammad Mahmudul Islam, Sayedur Rahman Chowdhury, and M. Shahadat Hossain. 2016. Heavy Metals Accumulation in Coastal Sediments. In Environmental Remediation Technologies for Metal-Contaminated Soils. Tokyo: Springer.

Siddiquee, Noman Ahmad, Selina Parween, M. M. A. Quddus, and Prabal Barua. 2012. Heavy Metal Pollution in Sediments at Shipbreaking Area of Bangladesh. In Coastal Environments: Focus on Asian Regions. Edited by V. Subramanian. New Delhi: Capital Publishing Company, pp. 78-87.

Snow, David A., and Robert D. Benford. 1988. Ideology, Frame Resonance, and Participant Mobilization. International Social Movement Research 1: 197-217.

Strauss, Anselm, and Juliet M. Corbin. 1997. Grounded Theory in Practice. Thousand Oaks: Sage.

Sujauddin, Mohammad, Ryu Koide, Takahiro Komatsu, Mohammad Mosharraf Hossain, Chiharu Tokoro, and Shinsuke Murakami. 2014. Characterization of shipbreaking industry in Bangladesh. Journal of Material Cycles and Waste Management 17: 72-83. [CrossRef]

Swyngedouw, Erik. 2000. Authoritarian governance, power, and the politics of rescaling. Environment and Planning D: Society and Space 18: 63-76. [CrossRef]

Swyngedouw, Erik, and Nikolas C. Heynen. 2003. Urban political ecology, justice and the politics of scale. Antipode 35: 898-918. [CrossRef]

The Daily Star. 2014. Two Illegal Ship-Breaking Yards Evicted after Five Years. Available online: http://www. shipbreakingbd.info/Two-illegal-ship-breaking-yards-evicted-after-five-years.html (accessed on 26 July 2017).

Transparency International. 2017. Corruption Perceptions Index 2016. Available online: https://www. transparency.org/news/feature/corruption_perceptions_index_2016 (accessed on 26 July 2017).

Wiktorowicz, Q. 2004. Islamic Activism: A Social Movement Theory Approach. Bloomington: Indiana University Press. YPSA. 2017. Youth Power in Social Action. Available online: http://ypsa.org/research-and-survey-reports / (accessed on 26 July 2017).

(C) 2018 by the authors. Licensee MDPI, Basel, Switzerland. This article is an open access article distributed under the terms and conditions of the Creative Commons Attribution (CC BY) license (http:// creativecommons.org/licenses/by/4.0/). 